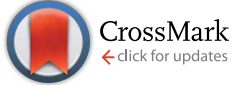

Cite this: RSC Adv., 2017, 7, 13896

Received 19th December 2016 Accepted 16th February 2017

DOI: $10.1039 / c 6 r a 28408 f$

rsc.li/rsc-advances

\section{Colorimetric detection of HVA by self-assembly of Au nanorods with DNA double helices to give side- by-side and end-to-end structures $\uparrow$}

\author{
Lin Chang, + Y Younas Khan, $\$$ Lidong Li, ${ }^{*}$ Nan Yang, Penggang Yin and Lin Guo \\ In this article we present the self-assembly of gold nanorods with DNA double helices into side-by-side and \\ end-to-end structures by the addition of HVA (hepatitis A virus Vall7 polyprotein gene). Between every two \\ gold nanorods, there is a distance of $10.2 \mathrm{~nm}$ which agrees with the length of DNA. By observing the change \\ in color with the naked eye or UV-Vis spectral absorbance, HVA concentration can be quantitatively \\ measured. The colorimetric detection has a linear relationship between the UV-Vis spectral absorbance \\ and the concentration, with a detectable range of $0.05 \mathrm{pM}$ to $35 \mathrm{pM}$. The standard deviation " $R^{2 \text { " value }}$ \\ was found to be $>0.99$. This method is simple, time economic and highly sensitive, and a lower limit of \\ detection up to 0.05 pM HVA can be achieved with great selectivity.
}

\section{Introduction}

Self-assembly promotes many good properties in nanoparticles such as unique optical, magnetic and electric properties and so on, which leads many scientists to pay close attention to selfassembly in nanoscale particles. ${ }^{1-5}$ Gold nanorods (Au NRs) have attracted wide interest due to their good optical properties, which result from the localized surface plasmon resonance, relative to the local dielectric environment. ${ }^{6-9}$ Self-assembled $\mathrm{Au}$ NRs have many potential applications in biology and science. ${ }^{10}$ A number of methods, for example using nano-templates, ${ }^{11}$ crystallization, ${ }^{12}$ bio-molecules, ${ }^{13}$ and small molecules ${ }^{14}$ have been reported to transform dispersed nanoparticles into desirable assembled structures. Many substances such as DNA, ${ }^{15}$ organic molecules, ${ }^{17-19}$ polymers, ${ }^{20}$ biotin-stre-pavidin connectors ${ }^{21}$ and those in the antibody-antigen reaction ${ }^{\mathbf{1 6}}$ can bring $\mathrm{Au}$ NRs together into ideal patterns through base pairing or physical and chemical affinities. Among these, DNA is a similar size to nanoscale particles and has a strong affinity for forming inter-connected structures ${ }^{22}$ based on oligonucleotide-gold nanorod conjugates (DNA-Au NR) by base sequence matching.

Due to their size and distance dependent optical properties and chemical stability, oligonucleotide-gold nanoparticle conjugates are found to be promising colorimetric probes. Until now, DNA-AuNP conjugates have been widely applied in the detection field, monitoring certain specific metal ions, organic

Key Laboratory of Bio-Inspired Smart Interfacial Science and Technology of Ministry of Education, School of Chemistry and Environment, Beihang University, Beijing, 100191, P. R. China.E-mail: lilidong@buaa.edu.cn

$\dagger$ Electronic supplementary information (ESI) available. See DOI: 10.1039/c6ra28408f

$\ddagger$ Both authors contributed equally to this work. molecules and some large molecules. ${ }^{23-27}$ Nam J. M. ${ }^{28}$ has used DNA-AuNPs to detect cancer biomarker proteins (PSA) with good sensitivity up to 3 attomolar. Jae-Seung Lee $^{29}$ has applied DNA-functionalized gold nanoparticles to the detection of $\mathrm{Hg}^{2+}$. Moreover, Min Su $\mathrm{Han}^{30}$ reported a simple detection method for an organic molecule using DNA-functionalized gold nanoparticles.

Hepatitis A is an acute infectious disease of the liver caused by the hepatitis A virus (HAV). ${ }^{31}$ Many cases have little to no symptoms especially in the young. The time between infection and symptoms is two to six weeks. When symptoms occur, they usually last eight weeks, with a fever, jaundice, diarrhea and abdominal pain. It usually spreads through close contact such as by drinking contaminated water or eating contaminated food with an infectious person. ${ }^{32}$ The hepatitis A virus Vall7 polyprotein gene (HVA) is the kind of polyprotein that exists in HAV, and can be used as a biomarker for HAV to identify infected people so that we can prevent the virus spreading. A number of methods have been used for the detection of HVA such as magnetic fluorescence ${ }^{33}$ with a detection limit up to $0.1 \mathrm{pM}$, Raman spectroscopy ${ }^{34}$ with a detection limit up to $1 \mathrm{pM}$, antibodies based on enzyme immunoassays (EIAs) and radioimmuno assays (RIAs) ${ }^{35}$ with detection limits up to $1 \mathrm{pM}$ and an SPR based colorimetric method with a detection limit up to $10 \mathrm{pM}^{36}$ But all these methods are quite complicated while some have limitations regarding sensitivity for detecting very small concentrations of HVA, so we need to develop an easy, sensitive and highly reliable method for early HVA detection.

In this work, we demonstrate the synthesis of Au NRs and the controllable self-assembly of Au NRs into novel structures including side-by-side and end-to-end structures through base pairing with DNA. Based on programmed assembly, we developed a colorimetric method observing a change in solution 
color from purple to light pink and used it in the early detection of the hepatitis A virus Vall7 polyprotein gene (HVA). Our method has some obvious advantages over the prevalent methods, firstly it is simple, easy and less time consuming. Secondly, it was found to be very sensitive for HVA. Finally, it is the first time that we have combined self-assembly and colorimetry to detect HAV and with a good result.

\section{Experimental section}

\subsection{Chemicals}

All the DNA and real blood serum samples were bought from Sangon Biotech (Shanghai) Co., Ltd. The sequences are listed in Table $1 . \mathrm{HAuCl}_{4} \cdot 4 \mathrm{H}_{2} \mathrm{O}$ was bought from Shenyang Jinke reagent company. Hexadecyltrimethylammonium bromide (CTAB), hexadecyltrimethylammonium chloride (CTAC), sodium oleate $(\mathrm{NaOL})$, silver nitrate $\left(\mathrm{AgNO}_{3}\right)$, sodium borohydride $\left(\mathrm{NaBH}_{4}\right)$, hydrochloric acid $(\mathrm{HCl}, 12.1 \mathrm{M})$, ascorbic acid (AA), tris(2carbonylethyl) phosphorus hydrochloride (TCEP), tris(hydroxyethyl)methyl amino methane $\left(\mathrm{C}_{4} \mathrm{H}_{11} \mathrm{NO}_{3}\right)$, magnesium chloride $\left(\mathrm{MgCl}_{2}\right)$, and sodium dodecyl sulfate (SDS) were brought from Beijing Chemical Works. All the reagents were analytical grade.

\subsection{Instruments}

Scanning electron microscope (SEM) images were obtained using a Hitachi S-4800. SEM samples were prepared by dropping the test solution onto a silicon chip and leaving it at room temperature until the solvent evaporated. Transmission electron microscopic (TEM) information was obtained using a JEM-2010F operating under a $200 \mathrm{kV}$ acceleration voltage. By dropping the sample solution onto a copper grid with 300 mesh, the test samples were prepared. UV-Vis spectra were obtained using an Alpha-1860C. The samples were prepared by dropping the solution into Ultra-Micro Cells with a thickness of $1 \mathrm{~cm}$ and the data was processed and acquired using Origin Lab software.

\subsection{Preparation of Au NRs}

The seed solution was synthesized as follows. Typically, $5 \mathrm{~mL}$ of $0.5 \mathrm{mM} \mathrm{HAuCl}_{4}$ and $5 \mathrm{~mL}$ of $0.2 \mathrm{M} \mathrm{CTAB}$ solutions were mixed in a $20 \mathrm{~mL}$ transparent vial. Then $1 \mathrm{~mL}$ of $0.006 \mathrm{M}$ fresh $\mathrm{NaBH}_{4}$ solution was added into the vial abovementioned under stirring at a speed of $1200 \mathrm{rpm}$ for $2 \mathrm{~min}$. The color of the solution transformed from yellow to brownish yellow.

Table 1 DNA names and sequences used in the experiment (control DNA 1 and 2 were used for the selectivity test)

\begin{tabular}{ll}
\hline DNA name & Sequence $\left(5^{\prime} \rightarrow 3^{\prime}\right)$ \\
\hline Helper & AAA AAA AAA AAA C $(6)$-SH \\
Target DNA & TTAGAGTTGCATGGATTAACTCCTCTTTCT $_{\text {Capture DNA 2 }}$ \\
Control DNA 1 & HS-C $_{(6)}$ AGAAAGAGGA \\
Control DNA 2 & TAAAGTTGCAGGGATTAACCCCCCTTTCT $^{\text {TAATATTTGCAGGGTTTAAATCCTCTTTCT }}$
\end{tabular}

Then the vials were placed at room temperature for aging for up to $30 \mathrm{~min}$. Next, we prepared the growth solution as follows: $1.234 \mathrm{~g}$ of $\mathrm{NaOL}$ and $6.15 \mathrm{~g}$ of CTAC were dissolved in $250 \mathrm{~mL}$ of water at $50{ }^{\circ} \mathrm{C}$, and were then transferred into a flask. When the temperature had cooled down to $30{ }^{\circ} \mathrm{C}, 18$ $\mathrm{mL}$ of $4 \mathrm{mM} \mathrm{AgNO}{ }_{3}$ solution and $250 \mathrm{~mL}$ of $1 \mathrm{mM} \mathrm{HAuCl}_{4}$ solution were added. Then the mixture was left at $30{ }^{\circ} \mathrm{C}$ for $15 \mathrm{~min}$, followed by stirring at $7000 \mathrm{rpm}$ for $150 \mathrm{~min}$. Subsequently, $5.0 \mathrm{~mL}$ of $12.1 \mathrm{M} \mathrm{HCl}$ was employed to adjust the solution to the proper $\mathrm{pH}$ which was followed by slow stirring at $400 \mathrm{rpm}$. Before strong stirring for $30 \mathrm{~s}, 1.25 \mathrm{~mL}$ of $0.064 \mathrm{M}$ AA was introduced. Finally, $0.8 \mathrm{~mL}$ of seed solution was dropped into the growth solution and afterwards the mixture was stirred for $30 \mathrm{~s}$, then it was kept still which was helpful for the NR's growth. The produced Au NRs were purified by centrifugation of the products for $25 \mathrm{~min}$ at $6000 \mathrm{rpm}$ which was repeated 3 times. $^{37}$

\subsection{Pretreatment of DNA}

Before using DNA as an interconnector, we added a certain amount of TCEP into the DNA solution (DNA was dissolved in $0.001 \mathrm{M}$ Tris-HCl buffer which included $20 \mathrm{mM} \mathrm{MgCl}_{2}$ and $0.01 \%$ SDS), then the DNA was heated to $90^{\circ} \mathrm{C}$ for $5 \mathrm{~min}$ to make it more flexible for the following base pairing. TCEP could reduce the disulfide bonds into individual $-\mathrm{SH}$ groups which were intended to react on the gold surface. ${ }^{38}$

\subsection{Self-assembly of Au NRs}

Freshly synthesized Au NRs were observed under the SEM (Fig. 1a) and have a length of $90 \pm 5 \mathrm{~nm}$ and a width of $25 \pm$ $5 \mathrm{~nm}$ and were well dispersed. To obtain side-by-side structures, two vials were needed. Helper DNA was added into two vials of $\mathrm{Au}$ NRs and incubated for $12 \mathrm{~h}$ at room temperature. Before incubating for another $12 \mathrm{~h}$, capture DNA 1 and capture DNA 2 in the same quantities were injected into each vial respectively. Then the two vials were mixed together in a big vial and target DNA was introduced into the big vial. The vial was then heated to $95{ }^{\circ} \mathrm{C}$ for $5 \mathrm{~min}$ and then the vial was allowed to cool down to room temperature. The helper DNA does not match any other DNA during the process of self-assembly. It is just a kind of DNA to be used as a barrier to control the regioselectivity of the selfassembly, so that we can obtain side-by-side structures. Capture DNA 1 and capture DNA 2 are employed in both the side-by-side structure and end-to-end structure to match with part of the complementary target DNA simultaneously at the ends. The target DNA is like a person with two hands, on the left it joins one of its hands with capture DNA 1 while on the right it joins the other hand with capture DNA 2. To obtain end-to-end structures, the process was similar to the process for side-byside assembly but in the absence of the helper DNA. Capture DNA 1 and capture DNA 2 were injected into two separate vials and incubated for $12 \mathrm{~h}$. Then the two vials were mixed together in a big vial and target DNA was introduced into the big vial. The vial was then heated to $95{ }^{\circ} \mathrm{C}$ for $5 \mathrm{~min}$ and then the vial was allowed to cool down to room temperature. 
a)
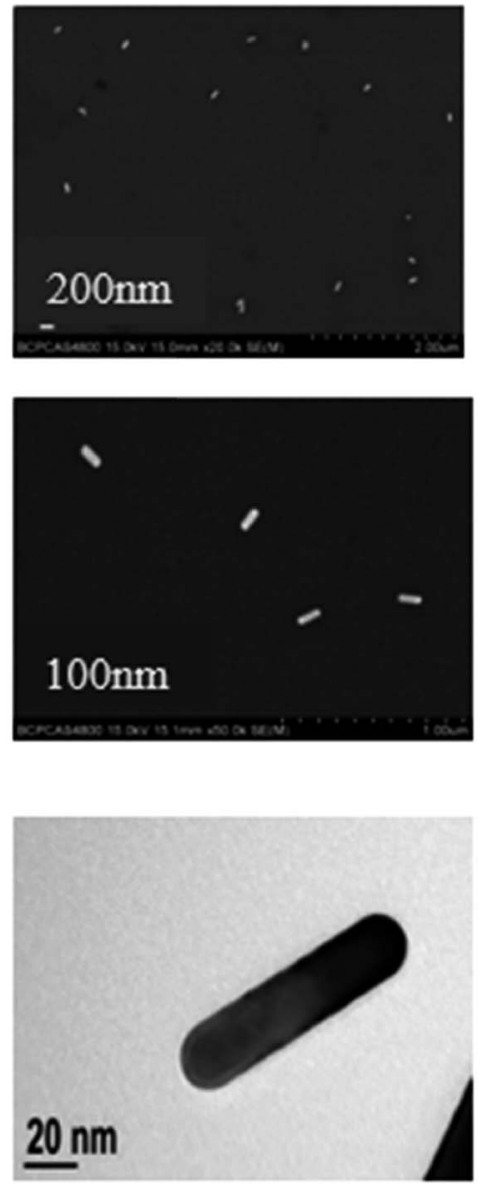

b)
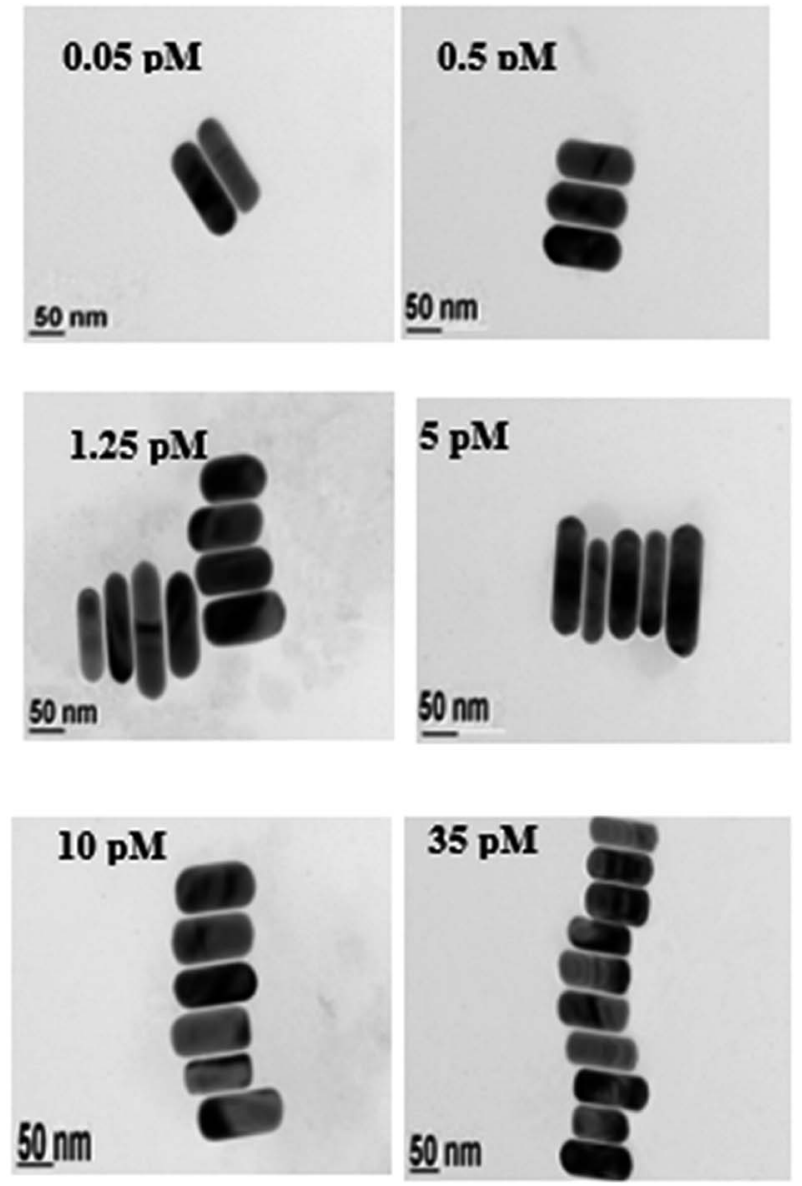

Fig. 1 (a) SEM images of dispersed Au NRs, the scale bars are $200 \mathrm{~nm}, 100 \mathrm{~nm}$ and $20 \mathrm{~nm}$; (b) TEM images of Au NRs assembled into side-by-side structures (the concentration of $\mathrm{C}_{1}$ and $\mathrm{C}_{2}$ was $33 \mathrm{pM}$, helper was $10 \mathrm{pM}$, and T was $0.05 \mathrm{pM} ; 0.5 \mathrm{pM} ; 1.25 \mathrm{pM} ; 5 \mathrm{pM} ; 10 \mathrm{pM}$; and $35 \mathrm{pM}$ ), the scale bar is $50 \mathrm{~nm}$.

\section{Results and discussion}

\subsection{Preparation of NR assemblies into regiospecific} geometries

Regular NRs (length: $90 \mathrm{~nm}$; width: $25 \mathrm{~nm}$ ) were synthesized by a classical seed-mediated growth method. Then their surfaces were modified by single-stranded DNA (ssDNA) at the ends (see Schemes 1 and 2).

During the process of the synthesis, there was still cetyltrimethylammonium bromide (CTAB) which remained coated on the surface of the Au NRs. CTAB preferred to bind to the $\{100\}$ facet which was the longitudinal side of the Au NRs, and left the $\{110\}$ facet ends of the Au NRs with a thinner

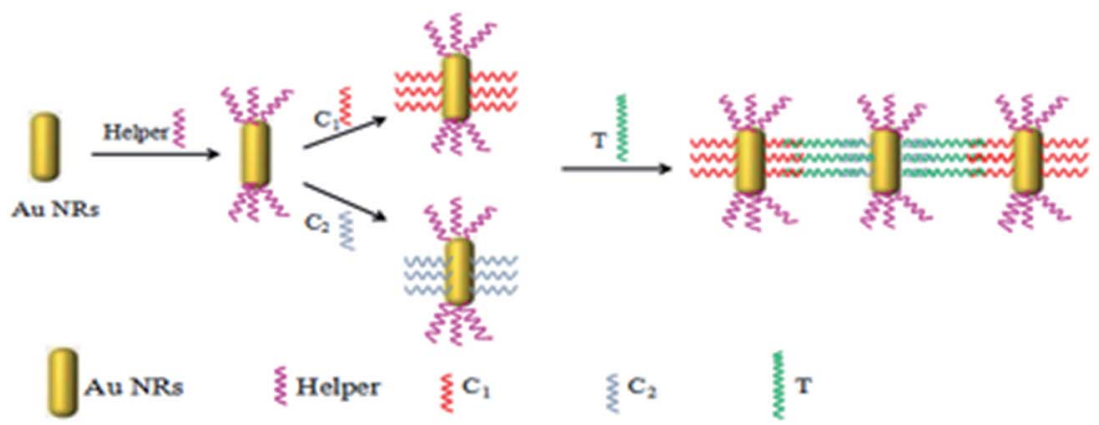

Scheme 1 Schematic of side-by-side self-assembly. 

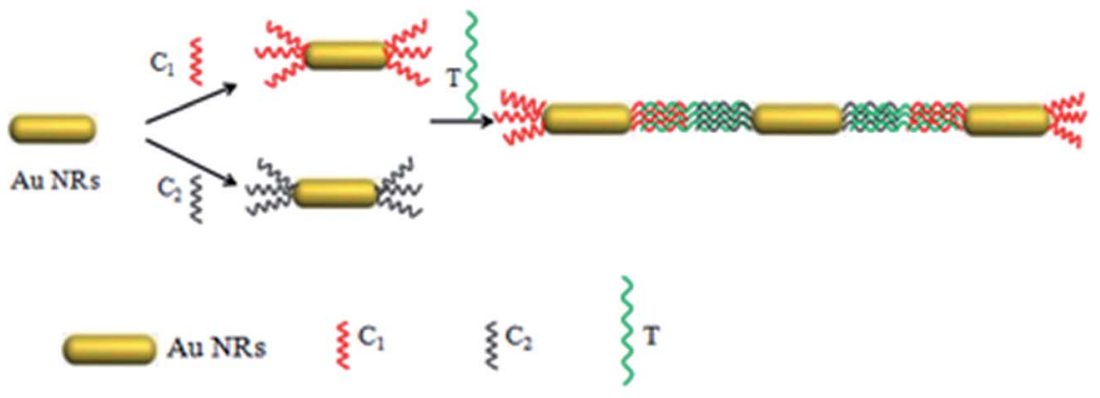

Scheme 2 Schematic of end-to-end self-assembly.

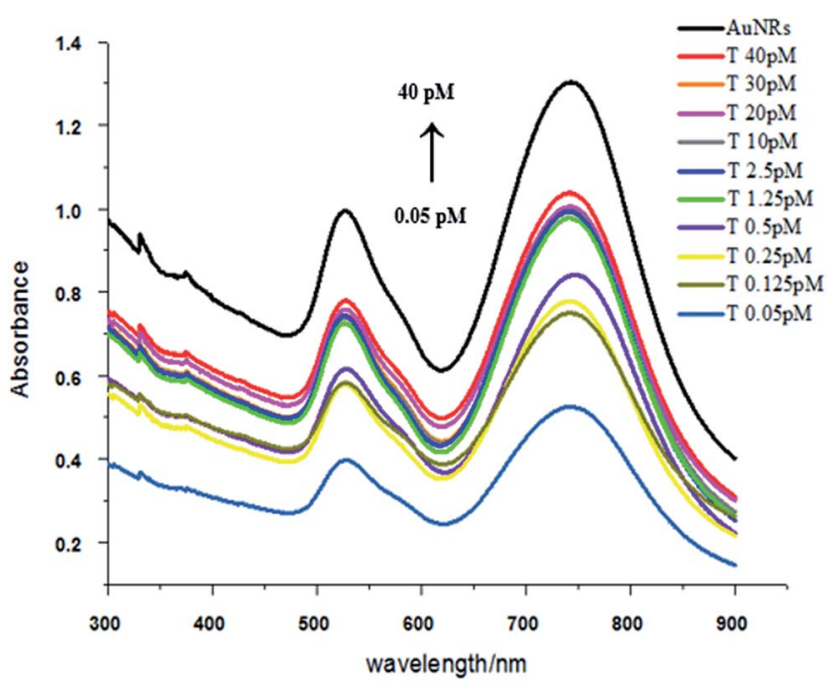

Fig. 2 UV-Vis spectrum of side-by-side assembly with a target DNA concentration range of $0.05-35 \mathrm{pM}$ (the concentration of $C_{1}$ and $C_{2}$ was $33 \mathrm{pM}$, and helper was $10 \mathrm{pM}$ ).

coating $^{39,40}$ than on their sides. So when in a low concentration of thiolated DNA, it will only attach at the ends and control the geometry.

In this work, two self-assembly methods of Au NRs are presented, side-by-side and end-to-end. These two distinct structures were obtained using different thiolated DNA samples with some specific sequences in an appropriate concentration. As such, we denoted a 10 base thiolated DNA sample with a sequence of GCAACTCTAA $\left.\mathrm{C}_{(6)}\right)^{-} \mathrm{SH}$ as capture DNA $1\left(\mathrm{C}_{1}\right.$ : red in Scheme 1) and another 10 base thiolated DNA sample with a sequence of $\mathrm{HS}^{-\mathrm{C}_{(6)}}$ AGAAAGAGGA as capture DNA $2\left(\mathrm{C}_{2}\right.$ : blue in Scheme 1). These two DNA samples had the same function, base pairing with a 30 base target DNA sample (T: green in Scheme 1) at each of the ends which had a sequence of TTA, GAG, TTG, CAT, GGA, TTA, ACT, CCT, CTT, or TCT. An assistant thiolated DNA sample was also employed named helper DNA (H: purple in Scheme 1) with a 15 base simple sequence of AAA AAA AAA AAA $\mathrm{C}_{(6)}-\mathrm{SH}$. The helper DNA is helpful to control the regioselectivity in the self-assembly process, especially during the side-by-side process, but does not match with any other oligomers.

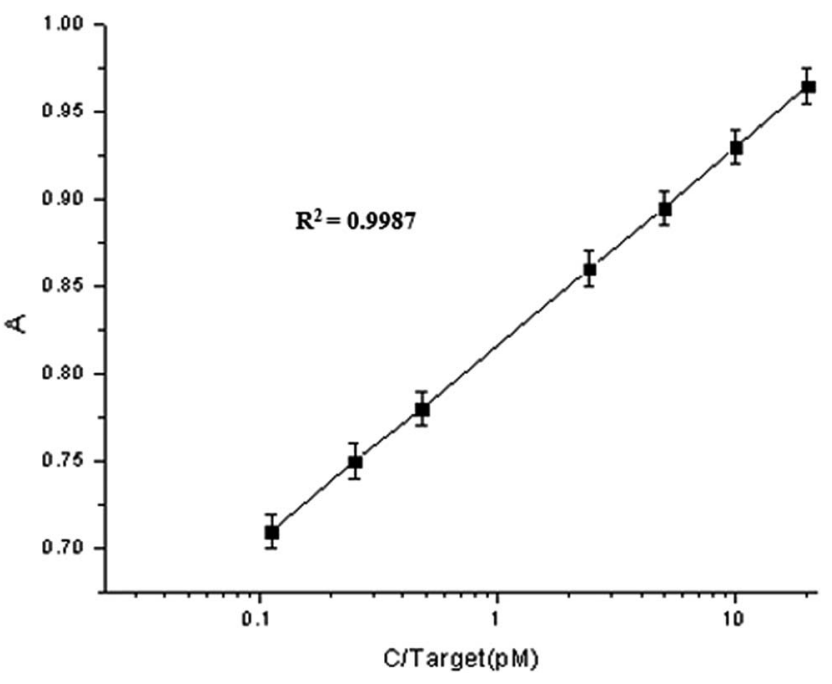

Fig. 3 Linear relationship between the absorbance with the change in concentration of target DNA $\left(C_{1}\right.$ and $C_{2}$ were $33 \mathrm{pM}$, and helper was 10 pM for side-by-side structures), T was $0.12 \mathrm{pM} ; 0.25 \mathrm{pM} ; 0.5 \mathrm{pM} ; 2.5$ $\mathrm{pM} ; 5.0 \mathrm{pM} ; 10 \mathrm{pM}$; and $20 \mathrm{pM}$. The error bars indicate the standard deviation of the seven successive measurements of a sample for each assay.

\subsection{Side-by-side self-assembly}

Because the ends have less CTAB on their surface and the ends of Au NRs are more active than the sides of Au NRs, ${ }^{\mathbf{4 1}}$ when the helper DNA at an appropriate concentration was added it had a preference to be absorbed at the ends (Scheme 1), which meant that the Au NRs' ends were occupied and that the sides were relatively more active. Then the Au NRs were modified with $\mathrm{C}_{1}$ (capture DNA 1) or $\mathrm{C}_{2}$ (capture DNA 2) on their sides, and once a concentration of target DNA between $0.05 \mathrm{pM}$ and $40 \mathrm{pM}$ was injected, there was an effective side-by-side self-assembly (TEM; Fig. 1b) which increased with the increase in target DNA concentration. After self-assembly, the optical properties were similar to nanowires (NWs), which was demonstrated using UV-Vis spectroscopy (Fig. 2). ${ }^{\mathbf{4 2 , 4 3}}$ With the increase in concentration of the target DNA in the range of $0.05-40 \mathrm{pM}$, the "nanowires" became fat, which was confirmed by a peak shift. The transverse peaks were inclining to blue shift (shorter wavelength) from $525 \mathrm{~nm}$ to $521 \mathrm{~nm}$ and decrease in amplitude while the longitudinal surface plasmon peaks red shifted 


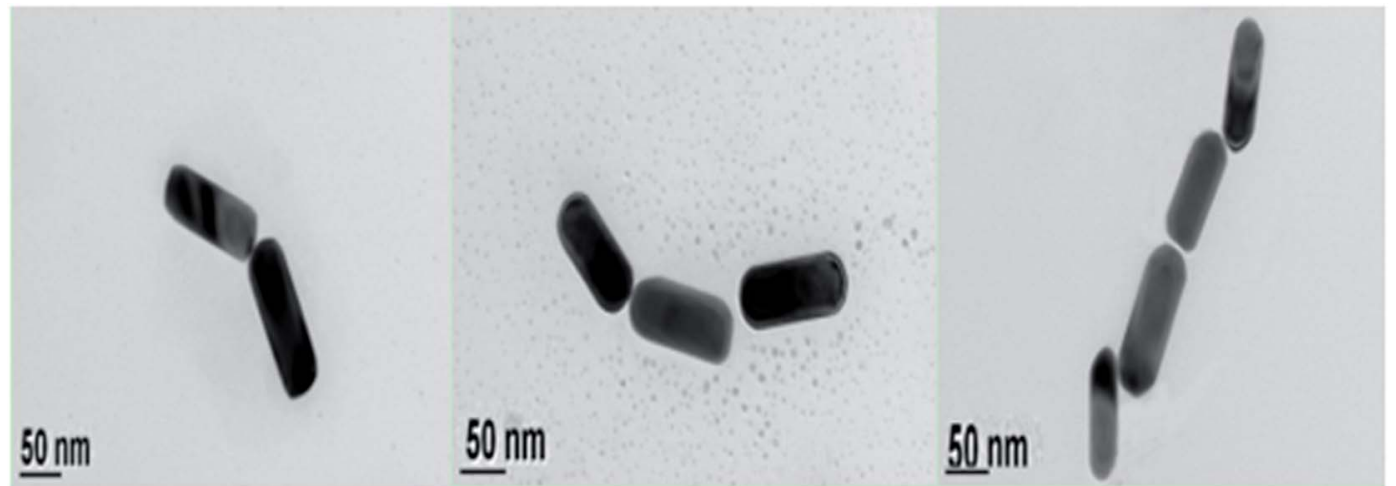

Fig. 4 TEM images of Au NRs assembled into end-to-end structures (the concentration of $C_{1}$ and $C_{2}$ was $33 \mathrm{pM}$ ), the scale bar is $50 \mathrm{~nm}$.

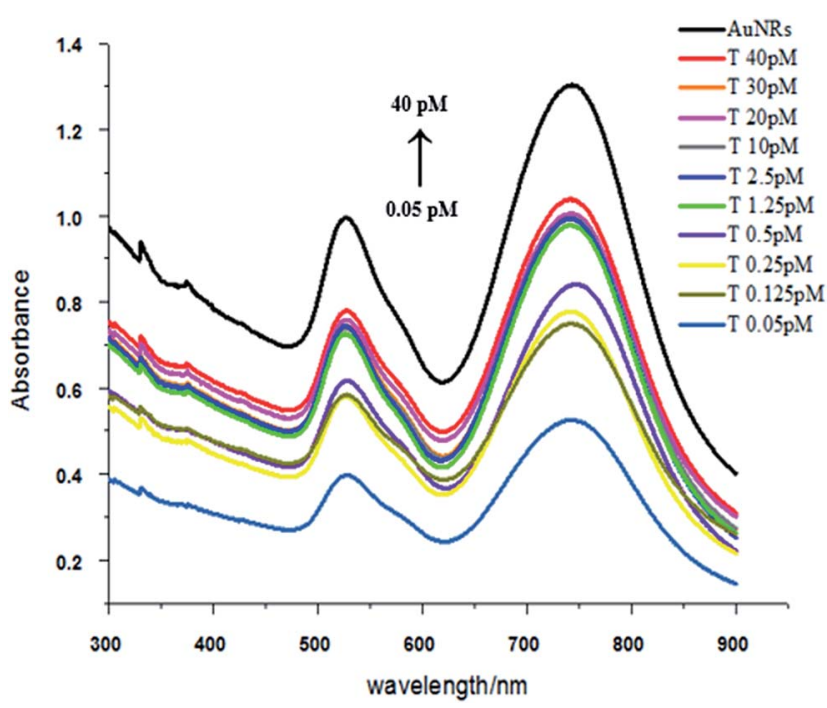

Fig. 5 UV-Vis spectra of end-to-end assembly with a target DNA concentration range of $0.05-40 \mathrm{pM}$ (the concentration of $\mathrm{C}_{1}$ and $\mathrm{C}_{2}$ was $33 \mathrm{pM}$ ).

(longer wavelength) from $742 \mathrm{~nm}$ to $751 \mathrm{~nm}$ and decreased in amplitude compared to the Au NRs' peaks. When the concentration of target DNA was lower than $0.05 \mathrm{pM}$, side-by-side selfassembly was not observed. When the concentration of target DNA was higher than $35 \mathrm{pM}$, the Au NRs aggregated. Under these two situations, we did not see the behavior of selfassembly, so in our work a target DNA concentration of 0.05$35 \mathrm{pM}$ was found to be optimum under our experimental conditions.

3.2.1 Colorimetric detection. During the process of side-byside self-assembly we found that the solution changed color from light pink to pink and finally became purple with increasing target concentration (Fig. S2 $\dagger$ ). This gave us a quantitative estimation of HVA concentration by observing the color with the naked eye. As shown in Scheme 1, because helper DNA was firstly added to preoccupy and passivate the ends of the $\mathrm{Au}$ nanorods, this left the sides of the Au nanorods open to hybridize with the capture DNA. Afterwards, the target DNA (HVA) was added to hybridize with the capture DNA 1 on the one

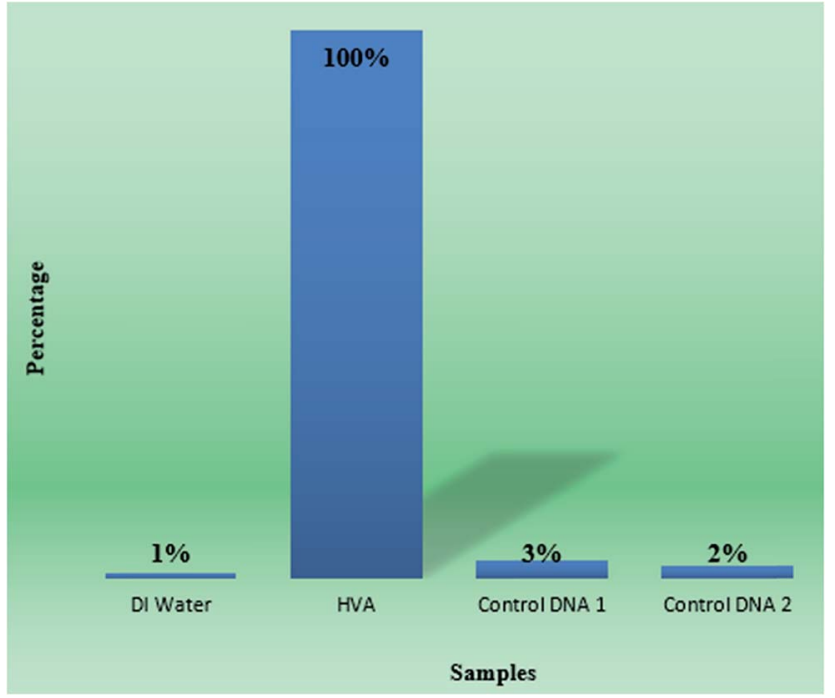

Fig. 6 The bar graph between second deionized water, 1 microlitre HVA, 1 microlitre control DNA 1 and 1 microlitre control DNA 2 shows the selectivity of the method, quantitatively.

side and hybridize with capture DNA 2 on the other side, then linking up all the capture DNA modified gold nanorods by attaching to each other side by side. Then aggregation occurs with an increased concentration of HVA. A linear relation between the target DNA concentration and absorbance was found during UV Visible spectroscopic studies of the various concentrations ranging from $0.5 \mathrm{pm}$ to $40 \mathrm{pm}$, as shown in Fig. 3. The linear correlation range was found between $0.5 \mathrm{pm}$ and $40 \mathrm{pm}$ with an $R^{2}$ value $>0.99$. This is the first time that a method has had a low detection limit of $0.05 \mathrm{pM}$ for target DNA (HVA) which is a part of the hepatitis A virus.

\subsection{End-to-end self-assembly}

Compared with the side-by-side structures, the procedure is easier to get end-to-end assembly structures. As show in Scheme 2, end-to-end assembly can be obtained without the addition of helper DNA. Because the ends of the Au nanorod are more active than the sides, adding an appropriate amount of $\mathrm{C}_{1}$ and $\mathrm{C}_{2}$ DNA 


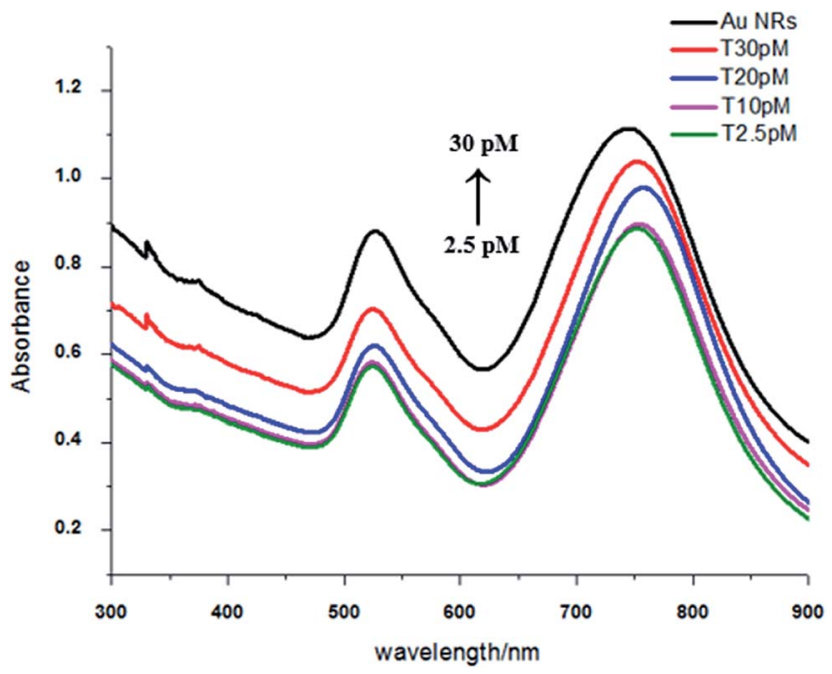

Fig. 7 UV-Vis spectra of the tests on real samples with side-to-side structures. In the samples, we added Au NRs, a real blood serum sample and HVA with concentrations of 2.5 pM, 10 pM, 20 pM, and 30 $\mathrm{pM}$.

Table 2 Recovery of HVA under different target DNA concentrations

\begin{tabular}{llll}
\hline (Target) $C_{0} / \mathrm{pM}$ & $A$ & $\begin{array}{l}\text { (Target) } \\
C / \mathrm{pM}\end{array}$ & Recovery (\%) \\
\hline 0.125 & 0.6998 & 0.1125 & 90 \\
0.25 & 0.7366 & 0.23 & 92 \\
0.5 & 0.7812 & 0.475 & 95 \\
1.25 & 0.8452 & 1.1625 & 93 \\
2.5 & 0.8801 & 2.30 & 94 \\
10 & 0.9485 & 9.4 & 94 \\
20 & 0.9934 & 18.6 & 93 \\
30 & 1.025 & 28.2 & 94
\end{tabular}

will firstly attach to the ends of the Au nanorod, and later addition of HVA will result in end-to-end assembly structures (TEM; Fig. 4). Similarly, with the concentration increase of target DNA, the nanowires became longer which was confirmed by peak shifting in the UV-Vis spectra compared to Au NRs' peaks. The transverse peaks remained unchanged in amplitude and wavelength while the longitudinal surface plasmon peaks red shifted (longer wavelength) from $745 \mathrm{~nm}$ to $749 \mathrm{~nm}$ and decreased in amplitude compared with Au NRs', as shown in Fig. 5. However, there is not a good calibration curve for the end-to-end structures (Fig. S1†).

\subsection{The selectivity of the colorimetric method}

Another vital factor for a colorimetric method is its selectivity which was tested here using a control experiment. Simultaneously, equal concentrations of $1.0 \mu \mathrm{L}$ double deionized water, 1.0 $\mu \mathrm{L}$ HVA, $1.0 \mu \mathrm{L}$ control DNA 1 and $1.0 \mu \mathrm{L}$ control DNA 2 were added into two solutions, one containing capture DNA 1 at 33 pM and one containing capture DNA 2 at $33 \mathrm{pM}$, which were both incubated at room temperature for $12 \mathrm{~h}$ and then mixed together. Observed from the colors of the solutions, only the vial where we added the target DNA had faded a little while the colors of the competitors stayed the same color as with the $\mathrm{Au}$ NRs. The results show that this method has good selectivity as shown in Fig. S3† and 6.

\subsection{Real sample analysis}

Many interruptions may occur when a real blood serum sample is employed in this analysis owing to the complexity of a real blood serum sample which can introduce some unknown bonding to the bulk sample. So we needed do some investigations to ensure whether the method was applicable to a real blood serum sample. Firstly, we diluted the blood serum fiftytimes, aiming to decrease the background noise in the real sample analysis application. Then under different concentrations of HVA with diluted serum, artificial physiological matrix and spiked serum samples were tested. The experimental data suggests that the method is applicable since the absorbance of the real blood serum samples was only decreased by 0.02 compared to the HVA in double deionized water sample, which was used as the background. So the dilution of a real blood serum sample to a large extent is good to diminish the background noise.

Then we applied the method to the real blood serum sample (Fig. 7) to test whether HVA gave similar results as in the previous experiment, and simultaneously we calculated the recovery of HVA as shown in Table 2. Recovery of HVA was calculated as the ratio between the concentration of added HVA and the detected concentration of HVA. In the table, we obtained very good recoveries between $90 \%$ and $94 \%$, which suggests the method has a promising future for use in biological samples.

\section{Conclusions}

Self-assembled oligonucleotide gold nanoparticle conjugates (DNA-AuNP) are found to be promising probes in bio-detection. We described the self-assembly of Au NRs synthesized by a seedmediated growth method into novel structures: side-by-side and end-to-end. An assay based on the side-by-side structures was developed to detect HVA, a polyprotein in hepatitis A virus. We found our method to be very sensitive with a lower limit of detection up to $0.05 \mathrm{pM}$. We achieved a linear relationship between the absorbance and the concentration in the range of

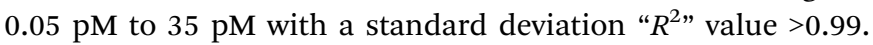
The novel side-by-side structure was attractive because it was convenient and rapid to synthesize and could be promising in detecting a variety of bio-molecules.

\section{Acknowledgements}

This work was financially supported by the National Natural Science Foundation of China (no. 21273001, 20973019, 20903008, and 50725208), with Key Project Funding by the NSFC (50831001 and 20973019), the NSFC for Outstanding Young Talents (507252008 and 10825419) and the National 
Basic Research Program of China (2014CB931802, 2010CB934700, and 2009CB623700).

\section{References}

1 R. D. Robinson, B. Sadtler, D. O. Demchenko, C. K. Erdonmez, L. W. Wang and A. P. Alivisatos, Spontaneous superlattice formation in nanorods through partial cation exchange, Science, 2007, 317(5836), 355-358.

2 S. J. Hurst, E. K. Payne, L. Qin and C. A. Mirkin, Multisegmented one-dimensional nanorods prepared by hard-template synthetic methods, Cheminform, 2006, 37(30), 2672-2692.

3 W. L. Shi, H. Zeng, Y. Sahoo, T. Ohulchanskyy, Z. L. Wang, M. SwiharAt and P. N. Prasad, A general approach to binary and ternary hybrid nanocrystals, Nano Lett., 2006, 6, 875-881.

4 Y. J. Min, M. Akbulut, G. Y. KristiansenK and K. Israelachvili, The role of interparticle and external forces in nanoparticle assembly, Nat. Mater., 2008, 7(7), 527-538.

5 N. Zhao, K. Liu, J. Greener, Z. Nie and E. Kumacheva, Closepacked superlattices of side-by-side assembled Au-CdSe nanorods, Nano Lett., 2009, 9(8), 3077-3081.

$6 \mathrm{M}$. A. El-Sayed, Some interesting properties of metals confined in time and nanometer space of different shapes, ChemInform, 2001, 34, 257-264.

7 C. T. Murphy, T. K. Sau, A. M. Gole, C. J. Orendorff, J. Gao, L. Gou, S. E. Hunyadi and T. J. Li, Anisotropic metal nanoparticles: synthesis assembly, and optical applications, J. Phys. Chem. B, 2005, 109, 13857-13870.

8 S. Link, M. B. Mohamed and M. A. El-Sayed, Simulation of the optical absorption spectra of gold nanorods as a function of their aspect ratio and the effect of the medium dielectric constant, J. Phys. Chem. B, 1999, 109(20), 3073-3077.

9 D. P. Sprunken, H. Omi, K. Furukawa, H. Nakashima, I. Sychugov, Y. Kobayashi and K. Torimitsu, Influence of the local environment on determining aspect-ratio distributions of gold nanorods in solution using Gans theory, J. Phys. Chem. C, 2007, 111(39), 14299-14306.

10 H. Nakashima, K. Furukawa, Y. Kashimura, et al., Selfassembly of gold nanorods induced by intermolecular interactions of surface-anchored lipids, Langmuir, 2008, 24(11), 5654-5658.

11 S. M. Marinakos, L. C. Brousseau, A. Jones and D. L. Feldheim, Template synthesis of one-dimensional Au, $\mathrm{Au}$-poly(pyrrole), and poly(pyrrole) nanoparticle arrays, Chem. Mater., 1998, 10(5), 1214-1219.

12 S. A. Harfenist, Z. L. Wang, R. L. Whetten, I. Vezmar and M. M. Alvarez, Three-dimensional hexagonal close-packed superlattice of passivated $\mathrm{Ag}$ nanocrystals, Adv. Mater., 1997, 9(10), 817-822.

13 C. J. Loweth, C. W. Brett, X. Peng, et al., DNA-based assembly of gold nanocrystals, Angew. Chem., Int. Ed., 1999, 38(12), 1808-1812.

14 X. Peng, T. E. Wilson, A. P. Alivisatos and P. G. Schultz, Synthesis and isolatin of a homodimer of cadmium selenide nanocrystals, Angew. Chem., Int. Ed., 1997, 36(1-2), 145-147.

15 E. Dujardin, L. B. Hsin, C. R. C. Wang and S. Mann, DNAdriven self-assembly of gold nanorods, Chem. Commun., 2001, (14), 1264-1265.

16 J. Y. Chang, H. M. Wu, H. Chen, Y. C. Ling and W. H. Tan, Oriented assembly of $\mathrm{Au}$ nanorods using biorecognition system, Chem. Commun., 2005, (8), 1092-1094.

17 M. M. Kathryn, S. Y. Lee, H. W. Liao, B. C. Rostro, A. Fuentes, P. T. Scully, C. L. Nehl and J. H. A. Hafner, Label-free immunoassay based upon localized surface plasmon resonance of gold nanorods, ACS Nano, 2008, 2(4), 687-692.

18 C. X. Yu and J. Irudayara, Multiplex biosensor using gold nanorods, Anal. Chem., 2007, 79, 572-579.

19 W. He, C. Z. Huang, Y. F. Li, J. P. Xie, R. G. Yang, P. F. Zhou and J. Wang, One-step label-free optical genosensing system for sequence-specific DNA related to the human immunodeficiency virus based on the measurements of light scattering signals of gold nanorods, Anal. Chem., 2008, 80(22), 8424-8430.

20 R. B. Grubbs, Nanoparticle assembly: solvent-tuned structures, Nat. Mater., 2007, 6(8), 553-555.

21 H. Park, A. Agarwal, N. A. Kotov and O. D. Lavrentovich, Controllable side-by-side and end-to-end assembly of $\mathrm{Au}$ nanorods by lyotropic chromonic materials, Langmuir, 2008, 24(24), 13833-13837.

22 C. J. Loweth, C. W. Brett, X. Peng, et al., DNA-based assembly of gold nanocrystals, Angew. Chem., Int. Ed., 1999, 38(12), 1808-1812.

23 I. Stoeva Savka, J.-S. Lee, T. C. Shad, et al., Multiplexed DNA detection with biobarcoded nanoparticle probes, Angew. Chem., Int. Ed., 2006, 45(20), 3303-3306.

24 C. M. Niemeyer and U. Simon, DNA-based assembly of metal nanoparticles, Eur. J. Inorg. Chem., 2005, 18, 3641-3655.

25 D. J. Maxwell, J. R. Taylor and S. Nie, Self-assembled nanoparticle probes for recognition and detection of biomolecules, J. Am. Chem. Soc., 2002, 124(32), 9606-9612.

26 M. G. Cerruti, M. Sauthier, D. Leonard, D. Liu, G. Duscher, D. L. Feldheim and S. Franzen, Gold and silica-coated gold nanoparticles as thermographic labels for DNA detection, Anal. Chem., 2006, 78(10), 3282-3288.

27 L. He, M. D. Musick, S. R. Nicewarner, F. G. Salinas, S. J. Benkovic, M. J. Natan and C. D. Keating, Colloidal Auenhanced surface plasmon resonance for ultrasensitive detection of DNA hybridization, J. Am. Chem. Soc., 2000, 122(122), 9071-9077.

28 J. M. Nam, C. S. Thaxton and C. A. Mirkin, Nanoparticlebased bio-barcodes for the ultrasensitive detection of proteins, Science, 2003, 301(5641), 1884-1886.

29 J. S. Lee, M. S. Han and C. A. Mirkin, Colorimetric detection of mercuric ion $\left(\mathrm{Hg}^{2+}\right)$ in aqueous media using DNAfunctionalized gold nanoparticles, Angew. Chem., Int. Ed., 2007, 46, 4093-4096.

30 M. S. Han, A. K. R. Lytton-Jean and C. A. Mirkin, A gold nanoparticle based approach for screening triplex DNA binders, J. Am. Chem. Soc., 2006, 128(15), 4954-4955. 
31 K. J. Ryan and C. G. Ray, Sherris Medical Microbiology, McGrawHill, 4th edn, 2004, pp. 541-544, ISBN 0-83858529-9.

32 S. C. Matheny, J. E. Kingery and A. Hepatitis, Am. Fam. Physician, 2012, 86(11), 1027-1034.

33 Y. Liu, X. Zhang, E. Yifeng, F. Fang, et al., Sandwich Immunoassays of Multicomponent Subtrace Pathogenic DNA Based on Magnetic Fluorescent Encoded Nanoparticles, BioMed Res. Int., 2015, 2016, 1-9.

34 J. Irudayaraj, Biomedical Nanosensors, Pan standford, 2012, vol. 3, pp. 104-106, ISBN (978-9-81430-304).

35 D. Liu, Molecular detection of human viral pathogens, CRC press united states, 2011, vol. 13, pp. 28-30, ISBN(978-14398-1237-2).

36 Y. Liu, W. Fang, et al., A one-tube multiplexed colorimetric strategy based on plasmonic nanoparticles combined with non-negative matrix factorization, Talanta, 2014, 128, 305310.

37 M. S. Han, A. K. R. Lytton-Jean and C. A. Mirkin, A gold nanoparticle based approach for screening triplex DNA binders, J. Am. Chem. Soc., 2006, 128(15), 4954-4955.
38 X. Ye, Y. Gao, J. Chen, et al., Seeded growth of monodisperse gold nanorods using bromide-free surfactant mixtures, Nano Lett., 2013, 13(5), 2163-2171.

39 L. D. Li, H. T. Zhao, Z. B. Chen, et al., Aptamer biosensor for label-free impedance spectroscopy detection of thrombin based on gold nanoparticles, Sens. Actuators, B, 2011, 157(1), 189-194.

40 L. B. Wang, Y. Y. Zhu, L. G. Xu, W. Chen, H. Kuang, L. Q. Liu, A. Agarwal, C. L. Xu and N. A. Kotov, Angew. Chem., Int. Ed., 2010, 49, 5472.

41 Z. H. Nie, D. Fava, M. Rubinstein and E. Kumacheva, "Supramolecular" assembly of gold nanorods endterminated with polymer "pom-poms": effect of pom-pom structure on the association modes, J. Am. Chem. Soc., 2008, 130, 3683.

42 L. Xu, H. Kuang, C. Xu, et al., Regiospecific plasmonic assemblies for in situ Raman spectroscopy in live cells, $J$. Am. Chem. Soc., 2012, 134(3), 1699-1709.

43 J. M. Humphrey, J. B. Aggen and A. R. Chamberlin, Total synthesis of the serine-threonine phosphatase inhibitor microcystin, J. Am. Chem. Soc., 1996, 118, 11759-11770. 